DOI

\title{
РОЛЬ САМОСТІЙНОЇ РОБОТИ СТУДЕНТІВ В ОРГАНІЗАЦІЇ НАВЧАЛЬНОГО ПРОЦЕСУ
}

\author{
В. М. Мерецький
}

ДВНЗ “Тернопільський державний медичний університет

імені І. Я. Горбачевського МОЗ України”

\section{ROLE OF INDEPENDENT WORK OF STUDENTS IN THE EDUCATIONAL PROCESS ORGANIZATION}

\author{
V. M. Meretskyi \\ SHEI “Ternopil State Medical University by I. Ya. Horbachevsky of MPH of Ukraine”
}

\begin{abstract}
У статті обговорюється питання організації самостійної роботи студентів при вивченні предмета “Клінічна фармакологія”. Звертається увага на методичні підходи до її вдосконалення, спрямовані на підвищення якості підготовки лікарів.
\end{abstract}

The article discusses the organization of independent work of students in the study of the subject "Clinical Pharmacology". Attention is drawn to the methodological approaches of independent work perfection directed towards increasing the training level of doctors.

Вступ. У сучасному соціокультурному просторі особливої значущості набуває виховання активного громадянина, відповідальної, творчої особистості, здатної до постійного самовиховання і саморозвитку, спроможної реалізувати свій потенціал на користь суспільству. На розв'язання цих завдань спрямовані Національна доктрина розвитку освіти України в XXI столітті, Закон України “Про вищу освіту”, Програма щодо реалізації положень Болонської декларації в системі вищої освіти і науки України $[1,2]$. Сучасні досягнення науки і широке впровадження наукових технологій у виробничі процеси всіх галузей, у тому числі і у сферу медичного обслуговування населення, кардинально змінили не тільки умови трудового процесу, а й високо підняли планку вимог до випускників вищих навчальних закладів (ВНЗ). Сучасна система вищої медичної освіти покликана готувати молодих фахівців з високим рівнем теоретичної підготовки зі своєї лікарської спеціальності, здатних швидко i ефективно реагувати на сучасні досягнення медичної науки, які володіють широким спектром клінічного мислення та навичками епідеміологічної оцінки ситуації, готових впроваджувати нові технології в практичну охорону здоров’я [3].

() В. М. Мерецький
Вирішення цієї задачі неможливе тільки шляхом передачі знань у готовому вигляді від викладача до студента. Необхідно перевести студента з пасивного споживача знань в активного їх творця, що вміє сформулювати проблему, проаналізувати шляхи їі вирішення. У цьому плані самонавчання як елемент самостійної роботи студентів (СРС) є важливою формою і основою освітнього процесу [4]. В останнє десятиліття при реалізації навчального процесу у вищих навчальних закладах широко використовуються різні інноваційні технології. Зокрема, інновації в освіті проявляються в тенденціях накопичення і видозміни ініціатив і нововведень в освітньому просторі (нові методики і прийоми навчання), які зумовлюють зміни у сфері освіти i трансформацію його змісту і якості на більш високий рівень [3].

Самостійна робота $є$ однією з основних складових професійної підготовки студентів у вузі, спрямована на саморозвиток необхідних здібностей майбутнього випускника до більш складних, поліфункціональних видів діяльності та забезпечує формування мобільних, здатних до конкуренції, інноваційної та управлінської діяльності кваліфікованих кадрів [5].

Здійснення аудиторної самостійної роботи вимагає від студентів виконання певного мінімуму 
дій: розуміння і усвідомлення навчального завдання, вироблення програми дій, чітке визначення мети та способів її досягнення, результативний самоконтроль у процесі виконання всіх названих дій. Вона передбачає також відповідальність та ініціативність студента, вміння робити аналіз своєї навчальної діяльності і давати самооцінку. Позааудиторну самостійну роботу студент організовує самостійно за запропонованою викладачем схемою. Цей вид роботи доповнює самостійну аудиторну роботу, яка відбувається під безпосереднім активним керівництвом викладача [6]. Враховуючи вищенаведене, важливого значення набуває проблема активізації самоосвітньої діяльності студента медичного університету.

Мета статті полягала у розширенні контенту самостійної роботи студентів при вивченні дисципліни “Клінічна фармакологія”.

Основна частина. Самостійна робота розглядається, з одного боку, як вид діяльності, що стимулює активність, самостійність, пізнавальний інтерес, і як основа самоосвіти, поштовх до подальшого підвищення кваліфікації, а $з$ іншого як система заходів або педагогічних умов, що забезпечують керівництво самостійною діяльністю студентів [3]. Аналіз літератури дозволяє констатувати, що можливості самоосвітньої діяльності студента зростають із підвищенням рівня його самосвідомості, збагаченням мотиваційної сфери, накопиченням знань і досвіду самостійної роботи, умінням оптимально використовувати методи, засоби і прийоми самовдосконалення, створенням позитивного емоційного фону самовдосконалення, розвитком вольової сфери, відповідною організацією навчально-виховного процесу. Важливим фактором ефективності самостійної роботи студента виступає система педагогічного забезпечення його активності в навчальному процесі, тобто активізація самовдосконалення і саморозвитку $[1,6]$.

Клінічна фармакологія викладається на заключних етапах навчання у ВНЗ (5 курс медичний факультет, 4 курс стоматологічний факультет). За порівняно короткий період існування в умовах стрімкого розвитку фармацевтичного ринку її місце в структурі вищої медичної освіти як навчальної дисципліни набуло великого значення. До теперішнього часу є значна кількість лікарських речовин, накопичений величезний матеріал, що відображає їх фармакокінетику і фармакодинаміку, молекулярні і субмолекулярні механізми дії, побічні явища, протипоказання до призначення. Не припиняєть- ся пошук і створення нових лікарських речовин, що володіють високою специфічною активністю і низькою токсичністю [7, 8]. Виходячи з цього, предмет посів важливе місце в системі вузівської підготовки, що обумовлено його значимістю у формуванні клінічного мислення майбутнього спеціаліста з опануванням ним новітніх досягнень світової фармакології та фармації [9]. Організація педагогічного процесу з клінічної фармакології будується з позиції орієнтації її на кінцеву мету - засвоєння студентом навичок раціонального застосування лікарських засобів в умовах клініки. Майбутній лікар повинен не тільки навчитись використовувати на практиці основні принципи вибору ефективної та безпечної фармакотерапії, а також засвоїти запобіжні й захисні заходи при виникненні побічної дії та ускладнень, опанувати основні правила призначення комбінованої фармакотерапії [9].

Самостійна робота студентів при вивченні клінічної фармакології являє собою єдність трьох форм: позааудиторної самостійної роботи, аудиторної самостійної роботи, що здійснюється під безпосереднім керівництвом викладача, та творчої роботи.

Підвищення ефективності СРС можливе за виконання ряду умов: забезпечення оптимального поєднання обсягів аудиторної та позааудиторної самостійної роботи; методично правильна організація аудиторної та позааудиторної діяльності студента; забезпечення навчальною літературою, методичними розробками та електронними ресурсами; контроль за виконанням самостійної роботи; застосування заходів щодо підвищення мотивації студентів та заохочення їх за якісне виконання самостійної роботи. Важливою умовою ефективності самостійної роботи є мотивація студентів до отримання знань. Результати анкетування показують, що постійно поповнювати свої знання бажають 52 \% студентів старших курсів, в міру необхідності - $48 \%$ [10].

Самостійне вивчення предмета на практичному занятті полягатиме у проведенні різних видів ділових та рольових ігор, мета яких у можливості використання теорії у практиці, удосконалення отриманих вмінь та навиків в імітаційних умовах, виконанні проекту (клінічної задачі, ситуації, проблеми) з наступним публічним обговоренням та захистом свого варіанта, що підсилює прагнення до якісного виконання. У медичному вузі така робота $є$ особливо важливою, оскільки лікар обов'язково повинен вміти правильно формулювати свої думки, 
чітко обгрунтовувати прийняті рішення. Діяльність студентів за умов позааудиторної самостійної та творчої роботи може бути спрямована на підготовку та написання рефератів на задані теми, розробку та складання різних блок-схем, підготовку до участі у наукових конференціях, олімпіадах тощо.

Більшість студентів (87,6 \%) вважає, що самостійна робота $є$ неодмінною умовою для майбутньої успішної професійної діяльності лікаря. Значне число (83 \%) вважає, що шляхом самостійної діяльності можна сформувати професійно важливі якості лікаря, а також цілеспрямовано визначити сферу своєї наукової та практичної діяльності (54,5%) [10].

Створення найоптимальніших умов для розвитку особистих якостей майбутніх лікарів, наявність відповідного методичного забезпечення аудиторної та позааудиторної роботи, здійснення постійного контролю за роботою студентів, раціональний розподіл часу студентів, зацікавленість студентів роботою сприятимуть підвищенню якості СРС. Самостійна робота студентів $\epsilon$ не просто важливою формою освітнього процесу, а повинна стати його основою. Мова йде не тільки про збільшення числа годин на самостійну роботу. Посилення ролі СРС означає принциповий перегляд організації навчально-виховного процесу у ВН3, який повинен будуватися так, щоб розвивати вміння вчитися, формувати у студента здатність до саморозвитку, творчого застосування отриманих знань, способи адаптації до професійної діяльності в сучасному світі [3].

Висновок. Таким чином, самостійна робота студентів $є$ важливим елементом процесу підготовки висококваліфікованого лікаря, що дозволяє зробити студента активною фігурою навчального процесу, покращити якість навчання та сприяє залученню студентів у вирішення професійних завдань різної складності.

\section{Список літератури}

1. Бондар Л. А. Урізноманітнення форм та видів самостійної роботи студентів-філологів в умовах кредитномодульної системи організації навчального процесу / Л. А. Бондар // Педагогічний дискурс. - 2013. Вип. 14. - С. 87-92.

2. Шушляпин О. И. Личностно-ориентированный и групповой подход при самостоятельной работе в вузах: обоснование некоторых активных и инновационных методов обучения / О. И. Шушляпин // Новости медицины и фармации. - 2011. - №16 (379). - Режим доступа: http:// www.mif-ua.com/archive/article_print/21693

3. Ходжаян А. Б. Особенности организации эффективной самообразовательной деятельности студентов в медицинском вузе / А. Б. Ходжаян, Н. В. Агранович // Фундаментальные исследования. - 2011. № 11. - С. 149-153.

4. Самостоятельная работа студентов как ведущая форма организации учебного процесса на стоматологическом факультете / Т. В. Гайворонская, О. В. Гуленко, И. К. Севастьянова [и др.] // Международный журнал экспериментального образования. - 2013. - № 4. C. 74-78.

5. Кунцевич 3. С. Организация контролируемой самостоятельной работы студентов стоматологического факультета по дисциплине “Общая химия” / 3. С. Кун-

цевич // Свиридовские чтения : сб. ст. Вып. 8. - Минск, 2012. - С. 286-291.

6. Богиня Л. В. Самостоятельная работа как один из важнейших факторов подготовки иностранных студентов подготовительного отделения к обучению в вузе / Л. В. Богиня, Т. В. Савицкая, Л. В. Трусова // Світ медицини та біології. - 2013. - № 2. - С. 23-25.

7. Шайдуллина Л. Я. Клиническая фармакология - одна из стратегий Всемирной организации здравоохранения в области рационального использования лекарственных средств / Л. Я. Шайдуллина, Л. Е. Зиганшина // Казанский медицинский журнал. - 2012. - Т. 93, № 6. С. 916-920.

8. Goldstein D. J. The need for clinical pharmacology is greater than ever / D. J. Goldstein, P. K. Honig, S. Spielberg // Clin. Pharmacol. Ther. - 2008. - Vol. 83. - P. 213-217.

9. Особливості підготовки іноземних студентів на курсі клінічної фармакології з імунологією та алергологією / В. М. Бобирьов, Т. А. Петрова, Г. Ю. Островська [та ін.] // Світ медицини та біології. - 2013. - № 2. - С. 21-23.

10. Коновалова С. В. Самостоятельная работа студентов медицинского вуза / С. В. Коновалова, А. Ф. Амиров // Высшее образование в России. - 2010. - № 6. C. $156-159$. 